\title{
ANALISA PERBANDINGAN KUAT TEKAN BETON fc'-20,75 DENGAN DIRAWAT (CURING) DAN TIDAK DIRAWAT
}

\author{
Doni Rinaldi Basri ${ }^{*}$, Rahmat Tisnawan ${ }^{2}$, Wahyu B. Pribadi ${ }^{3}$ \\ 1) Teknik Sipil Universitas Abdurrab Pekanbaru Riau (email : doni.rinaldi@univrab.ac.id)

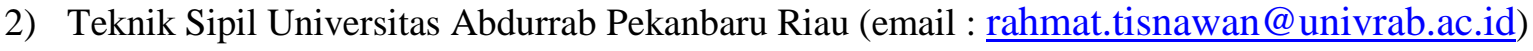 \\ 3) Teknik Sipil Universitas Abdurrab Pekanbaru Riau
}

\section{Info Artikel Riwayat Artikel: \\ Dikirim :28-04-2021 \\ Keywords : \\ Mutu beton \\ Kuat tekan beton \\ Curing beton}

Direvisi : 15-06- 2021

Diterbitkan: 28-06-2021

\begin{abstract}
$\underline{\text { ABSTRAK }}$
Untuk memahami dan mempelajari seluruh perilaku elemen gabungan pembentuk beton diperlukan pengetahuan tentang karakteristik masing-masing komponen pembentuk beton yaitu semen, agregat halus, agregat kasar dan air. Misalkan Semen A yang memiliki ketahanan yang tinggi terhadap sulfat, sehingga menghasilkan beton yang kuat dan bertekstur lebih halus. Sedangkan untuk Semen B adalah semen yang termasuk dalam kategori Blended Cement atau semen campur. Penelitian ini dilakukan untuk melihat perbandingan kuat tekan beton fc-20,75 dengan 2 (dua) merek semen yang berbeda, dengan metode perawatan (curing) dan tidak dirawat. Tujuan penelitian ini adalah untuk mengetahui nilai rata-rata dari hasil kuat tekan beton tersebut sehingga dapat dibandingkan hasil semen manakah yang lebih kuat. Berdasarkan hasil uji tekan didapatkan mutu beton tertinggi untuk Semen A sebesar 22,89 Mpa dan untuk Semen B sebesar 21,76 MPa. Sedangkan untuk beton yang tidak dilakukan perawatan, didapatkan mutu beton tertinggi 19,15 MPa untuk Semen A dan 17,41 MPa untuk Semen B. Artinya pemberian perawatan sangat berpengaruh tinggi dalam meningkatkan mutu kekuatan beton.
\end{abstract}

\section{PENDAHULUAN}

Beton merupakan bahan konstruksi yang paling banyak pemakaiannya di seluruh dunia dan digunakan secara luas di dunia sebagai bahan kontruksi selain baja dan kayu. Beton digunakan dihampir semua jenis konstruksi, seperti konstruksi diatas tanah (gedung dan jembatan), dibawah tanah (pondasi, terowongan) dan didasar laut (pipa minyak, anjungan lepas pantai). Hal ini antara lain disebabkan oleh mudahnya dalam memperoleh bahan penyusun beton dan kesederhanaan dalam pembuatan beton. Selain itu beton juga dapat dibuat dengan berbagaimutu dan dapat disesuaikan dengan kebutuhan konstruksi.
Beton diperoleh dengan cara mencampurkan beberapa bahan yang terdiri dari pasir, kerikil, semen, batu pecah atau agregat-agregat lain yang dicampur menjadi satu dengan suatu pasta yang terbuat dari semen dan air membentuk suatu massa mirip batuan. Terkadang, satu atau lebih bahan adiktif ditambahkan untuk menghasilkan beton dengan karakteristik tertentu, seperti kemudahan pengerjaan (workability), durabilitas, dan waktu pengerasan. Seperti substansi-substansi mirip batuan lainnya, beton memiliki kuat tekan yang tinggi dan kuat tarik yang sangat rendah (McCormac, 2004). 
Dalam pembuatan beton, ada hal - hal yang berpengaruh terhadap kekuatan (durability) beton, salah satunya adalah perawatan (curing). Perawatan (curing) beton yang baik umumnya menggunakan air bersih (air yang tidak mengandung kandungan kimia yang dapat merusak beton).

\section{METODE PENELITIAN}

Metode penelitian yang dilakukan adalah penelitian eksperimen dimana untuk mendapatkan data-data dan hasil penelitian dilakukan di Laboratorium Beton Jurusan Teknik Sipil Universitas Abdurrab, dengan tahapan sebagai berikut :

\section{a. Persiapan Alat dan bahan \\ Beton}

Beton adalah sebuah bahan bangunan komposit yang terbuat dari kombinasi agregat sebagai filler dan semen sebagai binder (Anam \& Trianto, 2013). Beton dibentuk dengan mencampur semen, agregat halus, agregat kasar dan air dengan atau tanpa bahan tambah dengan proporsi tertentu. Agregat merupakan komponen utama beton dengan mengisi sekitar $70 \%$ dari total volume beton. Semen digunakan sebagai bahan perekat sedangkan air sebagai bahan pembantu guna reaksikimia selama proses pengikatan dan perawatan beton.

\section{Material Penyusun Beton}

\section{Agregat}

Menurut SNI 03-1737-1989 yang dimaksud dengan agregat adalah sekumpulan butirbutir batu pecah, kerikil, pasir atau mineral lainnya, baik berupa hasil alam maupun hasil buatan. Agregat alam (uncrushed) adalah agregat yang didapat langsung dari alam seperti sungai dan gunung, sedangkan agregat buatan (crushed) adalah agregat yang didapat melalui proses mesin pemecah batu (stone crusher) sehingga dapat diperoleh agregat ukuran tertentu.

Agregat yang digunakan dalam campuran beton terdiri dari $60 \%$ sampai $75 \%$ dari volume totalnya. Agregat yang digunakan terdiri dari agregat kasar dan agregat halus. Agregat merupakan bagian yang jumlahnya terbesar dalam campuran, sehingga sebelum dipakai untuk campuran beton, kualitas (mutu) agregat harus diutamakan.

Menurut ukurannya agregat dapat dibedakan menjadi dua, yaitu agregat halus dan agregat kasar. Sesuai dengan SNI 03-2847-2002 bahwa agregat halus merupakan agregat yang mempunyai ukuran butir maksimum sebesar 5,00 mm. Agregat halus dapat berupa pasir alam, pasir hasil olahan atau gabungan dari kedua pasir tersebut. Agregat halus tidak boleh mengandung bagian yang lolos lebih dari $45 \%$ pada suatu ukuran ayakan dan tertahan pada ayakan berikutnya. Modulus kehalusan tidak boleh kurang dari 2,3 dan lebih dari 3,1. Sedangkan agregat kasar adalah agregat yang mempunyai ukuran butir antara 5,00 mm sampai $40 \mathrm{~mm}$. Agregat kasar dapat berupa kerikil, pecahan kerikil, batu pecah, teraktanurtiup atau beton semen hidrolis yang dipecah.

\section{Semen}

Semen adalah bahan pengikat pada pembentukan beton. Semen Portland adalah semen hidraulis yang dihasilkan dengan cara menghaluskan klinker yang terdiri dari silikat-silikat kalsium yang bersifat hidraulis bersama bahan tambahan yang biasanya digunakan adalah gypsum. Klinker adalah penamaan untuk gabungan komponen produk semen yang belum diberikan tambahan bahan lain untuk memperbaiki sifat dari semen (Nadia, 2011). Bahan pengikat hidrolis adalah bahan pengikat yang proses pengerasannya lebih baik dalam rendaman air serta menghasilkan produk yang tahan dengan air.

\section{Air}

Dalam pembuatan beton, air merupakan salah satu factor penting, karena air bereaksi dengan semen akan menjadi pasta pengikat agregat. Kualitas air sangat mempengaruhi kekuatan beton. Kualitas air erat kaitannya dengan bahan-bahan yang terkandung dalam air tersebut. Air diusahakan agar tidak membuat rongga pada beton, tidak membuat retak pada beton dan tidak membuat korosi pada tulangan yang mengakibatkan beton menjadi rapuh. 
Air yang dapat digunakan dalam proses pencampuran beton menurut SNI 03-28472002 adalah sebagai berikut :

a. Air yang digunakan pada campuran beton harus bersih dan bebas dari bahanbahan merusak yang mengandung oli, asam, alkali, garam, bahan organik, atau bahan-bahan lainnya yang merugikan terhadap beton atau tulangan.

b. Air pencampur yang digunakan pada beton prategang atau pada beton yang didalamnya tertanam logam aluminium, termasuk air bebas yang terkandung dalam agregat, tidak boleh mengandung ion klorida dalam jumlah yang membahayakan.

c. Air yang tidak dapat diminum tidak boleh digunakan pada beton, kecuali Pemilihan proporsi campuran beton harus didasarkan pada campuran beton yang menggunakan air dari sumber yang sama.

b. Pembuatan Job Mix Design (JMD) beton mutu FC-20,75

c. Penentuan kebutuhan material

d. Pencucian material agregat kasar dan halus

e. Pembuatan benda uji (dengan 2 merek semen)

f. Pemeliharaan beton (curring) \& tidak dirawat

\section{Curing}

Curing atau Perawatan Beton dilakukan saat beton sudah mulai mengeras yang bertujuan untuk menjaga agar beton tidak cepat kehilangan air dan sebagai tindakan menjaga kelembaban/suhu beton sehingga beton dapat mencapai mutu beton yang diinginkan. Pelaksanaan perawatan beton dilakukan setelah beton mengalami atau memasuki fase hardening (untuk permukaan beton yang terbuka) atau setelah bekisting beton dilakukan bongkaran dengan durasi tertentu yang dimaksudkan untuk memastikan terjaganya kondisi yang diperlukan untuk proses reaksi senyawa kimia yang terkandung dalam campuran beton. Proses curing pada beton berperan penting pada pengembangan kekuatan dan daya tahan beton. Proses curing meliputi pemeliharaan kelembaban dan kondisi suhu, baik di dalam beton maupun di permukaan beton dalam periode waktu tertentu.

Tujuan Perawatan (Curing) pada Beton:

a. Menjaga beton dari kehilangan air semen yang banyak -saat setting time concrete.

b. Menjaga perbedaan suhu beton dengan lingkungan yang terlalu besar.

c. Stabilitas dari dimensi struktur.

d. Mendapatkan kekuatan beton yang tinggi.

e. Menjaga beton dari kehilangan air akibat penguapan pada hari-hari pertama

f. Menjaga keretakan.

Husna (2016) melakukan penelitian kualitas dan kuat tekan beton yang menggunakan semen Holcim PCC tipe II dengan benda uji beton berbentuk kubus dengan dimensi $15 \mathrm{x}$ 15 x $15 \mathrm{~cm}$. Meskipun telah dilakukan perawatan, namun kuat tekan rencana tidak tercapai. Hal ini dikarenakan pengaruh kadar lumpur dalam air yang digunakan untuk campuran beton.

Hasibuan (2019) menyebutkan bahwa faktor lama perawatan dengan cara membungkus kubus beton menggunakan goni basah tidak signifikan terhadap kuat tekan beton. Sedangkan Faktor lama perawatan dengan cara merendam kubus beton dalam air berpengaruh nyata terhadap kuat tekan beton. Artinya tidak terdapat interaksi antara faktor cara perawatan dan faktor lama perawatan kuat tekan beton.

Penelitian kuat tekan beton dengan beberapa metode perawatan juga dilakukan oleh Angjaya et al (2013). Hasil penelitian terhadap benda uji silinder $10 / 20 \mathrm{~cm}$, berdasarkan 4 perilaku yang diterapkan, pada umur 3 hari perawatan oven 1 hari tanpa perendaman menghasilkan nilai kuat tekan yang paling tinggi dan pada umur 28 hari perawatan dengan perendaman menghasilkan nilai kuat tekan tertinggi.

Pada penelitian ini juga dilakukan tinjauan tentang kuat tekan beton dengan berbagai metode perawatan (Harjo, 2010; Rommel, 2011; Romadhoni; 2016; Supriyadi dan 
Islam, 2017; Prayuda dan Pujianto, 2018; Pazlan et al., 2019; Basri et al., 2019).

g. Pengujian kuat tekan umur 7, 14, 28 hari Menurut SNI 03-1974-1990 kuat tekan beton adalah besarnya beban per satuan luas, yang menyebabkan benda uji beton hancur bila dibebani dengan gaya tekan tertentu yang dihasilkan oleh mesin tekan. Kuat tekan beton (fc') dapat dihitung dengan rumus :

$\mathrm{Fc}^{\prime}=\mathrm{P} / \mathrm{A}$

dengan :

$\mathrm{Fc}^{\prime}=$ kuat tekan beton $(\mathrm{Mpa})$

$\mathrm{P}=$ beban tekan $(\mathrm{N})$

$\mathrm{A}=$ luas permukaan benda uji $(\mathrm{mm} 2)$

Kuat tekan beton dipengaruhi oleh beberapa faktor, diantaranya faktor air semen (FAS), workability, sifat dan jenis agregat, jenis campuran, serta perawatan dan umur beton. Faktor air semen sangat mempengaruhi kekuatan beton, FAS harus dihitung sehingga campuran air dan semen menjadi pasta yang baik. Artinya, tidak kelebihan air dan tidak kelebihan semen. Secara umum diketahui bahwa semakin tinggi nilai FAS, maka kekuatan beton akan semakin rendah. Penelitian kuat tekan beton dengan variasi FAS dilakukan oleh Prayuda et al (2018), dimana semakin kecil faktor air semen dapat membuat beton semakin tinggi kuat tekannya.

Sifat dan jenis agregat juga mempengaruhi kuat tekan beton. Semakin tinggi tingkat kekerasan agregat yang digunakan, maka kuat tekan yang dihasilkan juga akan semakin tinggi. Selain itu, susunan gradasi butiran agregat yang baik dan ketidakseragaman butiran agregat dapat memperkecil rongga antara agregat sehingga menghasilkan beton yang padat dan kuat tekan yang tinggi. Beton yang dihasilkan perlu mendapatkan perawatan dengan tujuan memperoleh proses hidrasi yang sempurna. Kuat tekan beton meningkat seiring bertambahnya umur beton, kekuatan beton dianggap dapat mencapai $100 \%$ setelah berumur 28 hari.

\section{h. Analisa dan Pembahasan}

Bagian ini berisi tentang analisis dan pembahasan terhadap hasil pengujian kuat tekan beton dengan membandingkan antara beton yang diberikan perlakukan dirawat dan tidak dirawat.

\section{i. Kesimpulan}

Sebagai penutup, maka diberikan kesimpulan dari hasil pengujian yang dilakukan berkaitan dengan kuat tekan beton.

\section{HASIL DAN PEMBAHASAN}

\subsection{Job Mix Design (JMD)}

Perhitungan campuran beton berdasarkan dari mix design yang digunakan pada salah satu pekerjaan yang dilakukan oleh PT. Riau Mas Bersaudara untuk mutu beton fc'20,75. Pada penelitian ini, untuk agregat kasar menggunakan batu pecah 1-2 dan batu pecah 2-3 dari batu bersurat. Untuk agregat halus (pasir) diambil dari Danau Bingkuang. Semen yang digunakan adalah merk semen A dan merk semen B. Data dan perhitungan kebutuhan material dapat dilihat pada Tabel 1 dibawah ini :

Tabel 1. Penimbangan untuk $1 \mathrm{M}^{3}$ Beton fc'20,75

\begin{tabular}{lcc}
\hline \multicolumn{1}{c}{ Bahan } & Berat Agregat $(\mathrm{Kg})$ & Kumulatif hasil penimbangan \\
\hline Pasir & 768 & 768 \\
\hline Batu Pecah 1-2 & 479 & 479 \\
\hline Batu Pecah 1-3 & 674 & 674 \\
\hline Semen & 315 & 315 \\
\hline Air & $188 \mathrm{Kg} / 188 \mathrm{ltr}$ & 188 \\
\hline
\end{tabular}

Sumber: Job Mix Desain PT. Riau Mas Bersaudara 


\section{Komposisi Campuran Material Untuk Satu} Sampel

Berikut adalah mix design yang akan digunakan pada penelitian ini. Komposisi perbandingan campuran beton dijelaskan sebagai berikut : Kebutuhan material untuk membuat $1 \mathrm{~m} 3$ beton menggunakan silinder:
1. Semen
$=315 \mathrm{Kg}$
2. Air

3. Agregat Halus $=768 \mathrm{Kg}$

4. Agregat Kasar 1-2 $(\mathrm{Kg})=479 \mathrm{Kg}$

5. Agregat Kasar $2-3(\mathrm{Kg})=674 \mathrm{Kg}$

Berikut ini adalah data mix design yang menjadi acuan pada penelitian ini dan kemudian akan dilakukan perhitungan kembali untuk komposisi material dalam satu sampel silinder dapat dilihat pada Tabel 2 di bawah ini.

Tabel 2. Komposisi untuk satu cetakan silinder (D 15 T 30)

\begin{tabular}{cccccc}
\hline Merek Semen & $\begin{array}{c}\text { Semen } \\
(\mathrm{kg})\end{array}$ & $\begin{array}{c}\text { Pasir } \\
(\mathrm{kg})\end{array}$ & $\begin{array}{c}\text { Batu Pecah 1-2 } \\
(\mathrm{kg})\end{array}$ & $\begin{array}{c}\text { Batu Pecah 2-3 } \\
(\mathrm{kg})\end{array}$ & $\begin{array}{c}\text { Air } \\
(\mathrm{kg})\end{array}$ \\
\hline $\mathrm{A}$ & 1,97 & 4.81 & 3.00 & 4.22 & 1.17 \\
\hline $\mathrm{B}$ & 1,97 & 4.81 & 3.00 & 4.22 & 1.17 \\
\hline
\end{tabular}

2. Pembuatan Benda Uji

Perencanaan campuran beton (mix design) mengacu pada aturan SNI 1974-2011 Setelah data/nilai campuran adukan beton diperoleh, selanjutnya melakukan pencampuran dengan mencampur agregat (kasar dan halus), semen, air beberapa persen yang telah ditentukan. Campuran tersebut dituangkan kedalam talam baja besar untuk dilakukan uji nilai slump, setelah nilai slump diperoleh masukkan campuran adukan beton kedalam cetakan silinder ukuran $15 \mathrm{~cm}$ x $30 \mathrm{~cm}$. Pengisian cetakan ditumbuk agar campuran mengisi rongga-rongga di dalam silinder. Jumlah benda uji yang akan dibuat pada penelitian ini adalah 18 benda uji.

Tabel 3. Rincian jumlah benda uji yang akan dibuat

\begin{tabular}{cccccc}
\hline \multirow{2}{*}{ Merek Semen } & \multicolumn{3}{c}{ Umur Rencana Beton (Hari) } & \multicolumn{2}{c}{ Perlakuan Beton } \\
\cline { 2 - 7 } & 7 & 14 & 28 & Dirawat (Curing) & Tidak Dirawat \\
\hline A & 3 & 3 & 3 & 6 & 3 \\
\hline B & 3 & 3 & 3 & 6 & 18 \\
\hline Jumlah & & 18 & & & 18 \\
\hline
\end{tabular}

\subsection{Analisa Hasil Pengujian}

Gambar 1 dibawah ini menjelaskan pengujian kuat tekan beton/sampel (semen A) dicuci pada umur 7 hari. Gambar (a) sampel beton sebelum dilakukan pengujian, gambar (b) menjelaskan keadaan atau kondisi sampel beton sesudah dilakukan pengujian kuat tekan beton, sedangkan untuk gambar (c) menunjukkan nilai kuat tekan sampel beton. Gambar 2 dibawah ini menjelaskan pengujian kuat tekan beton/sampel (semen B) yang dilakukan perawatan pada umur 7 hari (1). Gambar (a) sampel beton sebelum dilakukan pengujian, gambar (b) menjelaskan keadaan atau kondisi sampel beton sesudah dilakukan pengujian kuat tekan beton, sedangkan untuk gambar (c) menunjukan nilai kuat tekan sampel beton. 


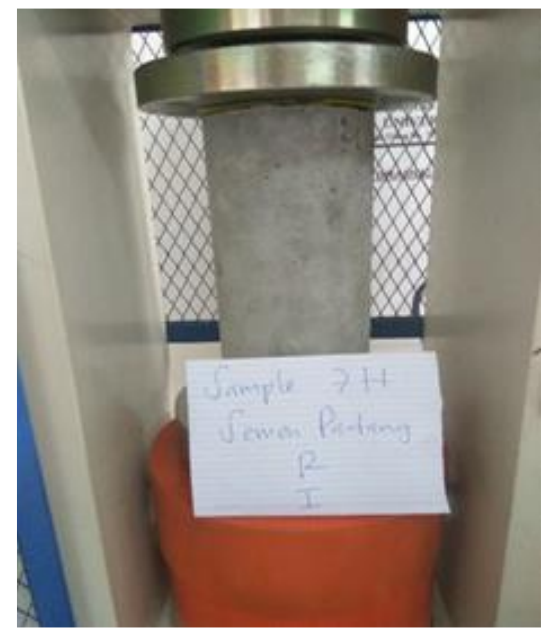

(a) Sampel sebelum diuji

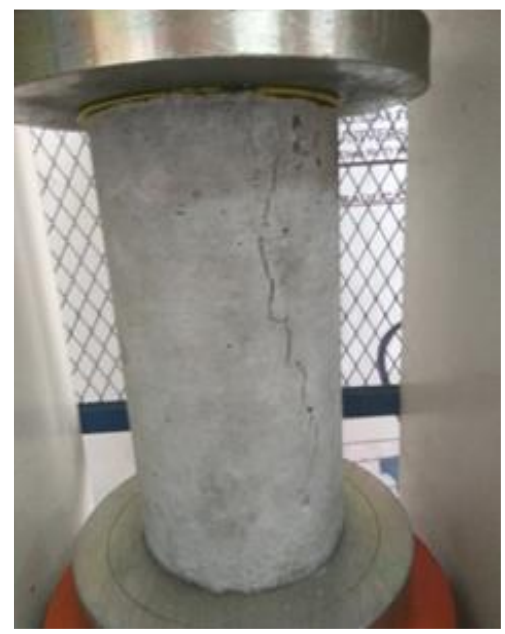

(b) Sampel setelah diuji

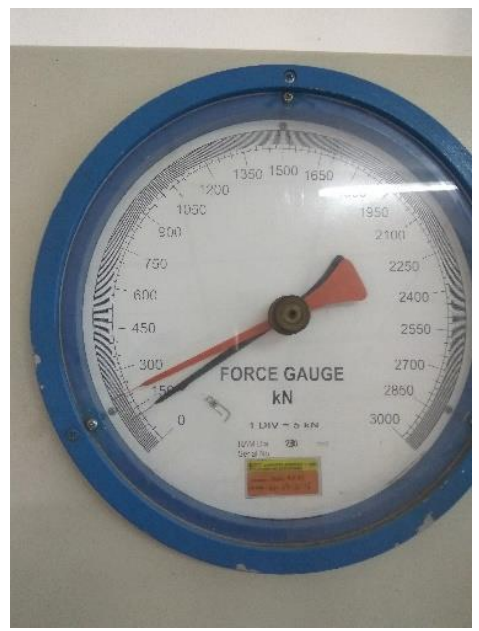

(c) Nilai kuat tekan sampel

Gambar 1. Pengujian Kuat Tekan Semen A Umur 7 hari (2) (curing)

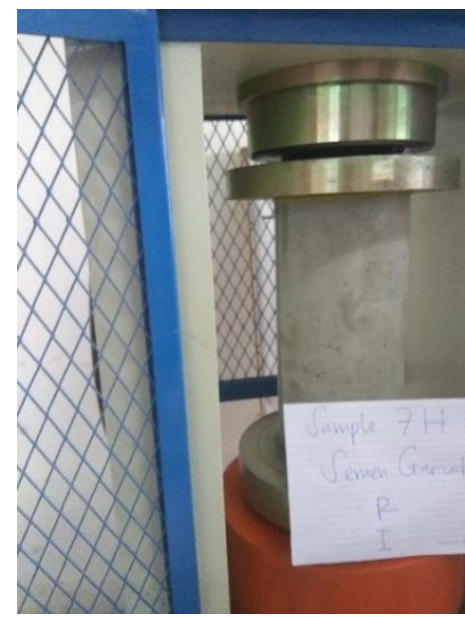

(a) Sampel sebelum diuji

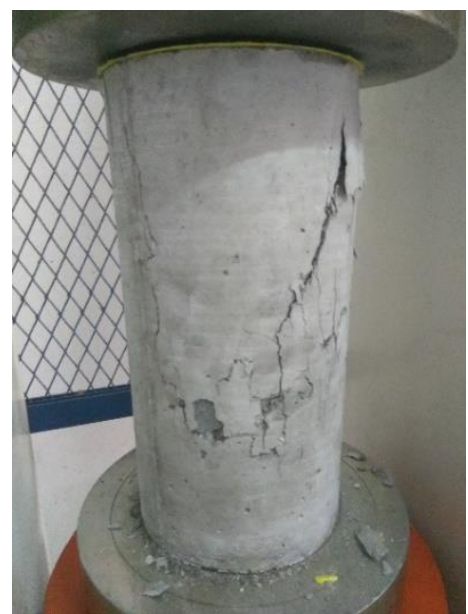

(b) Sampel setelah diuji

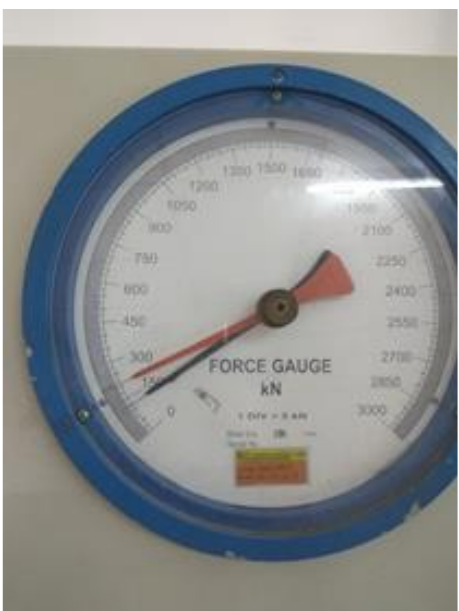

(c) Nilai kuat tekan sampel

Gambar 2. Pengujian Kuat Tekan Semen B Umur 7 hari (1) (curing)

Berdasarkan hasil pengujian pada Semen A didapatkan bahwa nilai kuat tekan beton untuk kondisi dirawat meningkat $8,43 \%$ dari 21,11 Mpa (umur 7 hari) menjadi 22,89 Mpa (umur 28 hari). Sedangkan kondisi beton yang tidak diberikan perawatan mengalami penurunan 17,28\% yaitu 19,15 Mpa (umur 7 hari) menjadi 15,84 Mpa. (umur 28 hari). Selanjutnya untuk Semen B didapatkan bahwa nilai kuat tekan beton untuk kondisi dirawat mengalami penurunan sebesar 3,77\% dari 21,76 Mpa (umur 7 hari) menjadi 20,94 Mpa (umur 28 hari). Sedangkan kondisi beton yang tidak diberikan perawatan mengalami penurunan $40,16 \%$ yaitu 17,41 Mpa (umur 7 hari) menjadi 10,47 Mpa. (umur 28 hari). Artinya perlakukan kondisi beton yang tidak dirawat dapat menurunkan kuat tekan sebesar $17,28 \%$ sampai dengan $40,16 \%$. Namun jika dilakukan perawatan dapat meningkat sebesar $8,43 \%$. Meskipun pada Semen B hasil pengujian kuat tekan menurun $3,77 \%$, namun tidak signifikan. Hasil pengujian dilakukan terhadap sampel umur 7, 14 dan 28 hari selengkapnya disajikan dalam Tabel 4 dan Tabel 5 dibawah ini : 
Tabel 4. Hasil Kuat Tekan Beton Menggunakan Semen A

\begin{tabular}{|c|c|c|c|c|c|c|c|c|c|c|c|c|c|}
\hline \multirow{2}{*}{$\begin{array}{l}\text { Nomor } \\
\text { Benda } \\
\text { Uji }\end{array}$} & \multirow{2}{*}{$\begin{array}{l}\text { Berat } \\
(\mathrm{Kg})\end{array}$} & \multicolumn{2}{|c|}{ Dimensi } & \multirow{2}{*}{$\begin{array}{l}\text { Slump } \\
\text { Test } \\
(\mathrm{cm})\end{array}$} & \multirow{2}{*}{$\begin{array}{l}\text { Umur } \\
\text { Beton } \\
\text { (Hari) }\end{array}$} & \multirow{2}{*}{$\begin{array}{c}\text { Luas } \\
\text { Penampang } \\
(\mathrm{mm} 2)\end{array}$} & \multirow{2}{*}{$\begin{array}{c}\text { Gaya } \\
\text { Tekan } \\
(\mathrm{kN})\end{array}$} & \multirow{2}{*}{$\begin{array}{c}\text { Kuat } \\
\text { Tekan } \\
\left(\mathrm{N} / \mathrm{mm}^{2}\right)\end{array}$} & \multirow{2}{*}{$\begin{array}{l}\text { Faktor } \\
\text { Umur } \\
\text { Beton }\end{array}$} & \multirow{2}{*}{$\begin{array}{l}\text { Faktor } \\
\text { Koreksi } \\
\text { Silinder }\end{array}$} & \multirow{2}{*}{$\begin{array}{l}\text { Mutu } \\
\text { Beton } \\
\text { (Mpa) }\end{array}$} & \multirow{2}{*}{$\begin{array}{l}\text { Mutu Beton } \\
\text { Rata-Rata } \\
\text { (Mpa) }\end{array}$} & \multirow{2}{*}{$\begin{array}{l}\text { Perlakuan } \\
\text { Beton }\end{array}$} \\
\hline & & $\begin{array}{c}\mathrm{L} \\
(\mathrm{mm})\end{array}$ & $\begin{array}{c}\mathrm{D} \\
(\mathrm{mm})\end{array}$ & & & & & & & & & & \\
\hline $1(7)$ & 12,850 & 300 & 150 & 9,83 & 7 & $17.671,5$ & 275 & 16 & 0,65 & 1 & 23,94 & \multirow{2}{*}{21,11} & Dirawat \\
\hline $2(7)$ & 12,855 & 300 & 150 & 9,83 & 7 & $17.671,5$ & 210 & 12 & 0,65 & 1 & 18,28 & & Dirawat \\
\hline $1(14)$ & 12,045 & 300 & 150 & 9,83 & 14 & $17.671,5$ & 330 & 19 & 0,88 & 1 & 21,22 & \multirow{2}{*}{21,54} & Dirawat \\
\hline $2(14)$ & 12,870 & 300 & 150 & 11,32 & 14 & $17.671,5$ & 340 & 19 & 0,88 & 1 & 21,86 & & Dirawat \\
\hline $1(28)$ & 12,840 & 300 & 150 & 11,32 & 28 & $17.671,5$ & 419 & 24 & 1 & 1 & 23,71 & \multirow{2}{*}{22,89} & Dirawat \\
\hline $2(28)$ & 12,975 & 300 & 150 & 11,32 & 28 & $17.671,5$ & 390 & 22 & 1 & 1 & 22,07 & & Dirawat \\
\hline $1(7)$ & 12,595 & 300 & 150 & 10,58 & 7 & $17.671,5$ & 220 & 12 & 0,65 & 1 & 19,15 & 19,15 & Tidak dirawat \\
\hline $1(14)$ & 12,035 & 300 & 150 & 10,58 & 14 & $17.671,5$ & 270 & 15 & 0,88 & 1 & 17,36 & 17,36 & Tidak dirawat \\
\hline $1(28)$ & 12,260 & 300 & 150 & 10,58 & 28 & $17.671,5$ & 280 & 16 & 1 & 1 & 15,84 & 15,84 & Tidak dirawat \\
\hline
\end{tabular}

Tabel 5. Hasil Kuat Beton Tekan Menggunakan Semen B

\begin{tabular}{|c|c|c|c|c|c|c|c|c|c|c|c|c|c|}
\hline \multirow{2}{*}{$\begin{array}{c}\text { Nomor } \\
\text { Benda } \\
\text { Uji }\end{array}$} & \multirow{2}{*}{$\begin{array}{l}\text { Berat } \\
(\mathrm{Kg})\end{array}$} & \multicolumn{2}{|c|}{ Dimensi } & \multirow{2}{*}{$\begin{array}{l}\text { Slump } \\
\text { Test } \\
(\mathrm{cm}) \\
\end{array}$} & \multirow{2}{*}{$\begin{array}{l}\text { Umur } \\
\text { Beton } \\
\text { (Hari) }\end{array}$} & \multirow{2}{*}{$\begin{array}{c}\text { Luas } \\
\text { Penampang } \\
(\mathrm{mm} 2)\end{array}$} & \multirow{2}{*}{$\begin{array}{l}\text { Gaya } \\
\text { Tekan } \\
(\mathrm{kN})\end{array}$} & \multirow{2}{*}{$\begin{array}{c}\text { Kuat } \\
\text { Tekan } \\
(\mathrm{N} / \mathrm{mm} 2)\end{array}$} & \multirow{2}{*}{$\begin{array}{l}\text { Faktor } \\
\text { Umur } \\
\text { Beton }\end{array}$} & \multirow{2}{*}{$\begin{array}{l}\text { Faktor } \\
\text { Koreksi } \\
\text { Silinder }\end{array}$} & \multirow{2}{*}{$\begin{array}{l}\text { Mutu } \\
\text { Beton } \\
\text { (Mpa) }\end{array}$} & \multirow{2}{*}{$\begin{array}{c}\text { Mutu Beton } \\
\text { Rata-Rata } \\
\text { (Mpa) }\end{array}$} & \multirow{2}{*}{$\begin{array}{l}\text { Perlakuan } \\
\text { Beton }\end{array}$} \\
\hline & & $\begin{array}{c}\mathrm{L} \\
(\mathrm{mm})\end{array}$ & $\begin{array}{c}\mathrm{D} \\
(\mathrm{mm})\end{array}$ & & & & & & & & & & \\
\hline $1(7)$ & 12,870 & 300 & 150 & 9,83 & 7 & $17.671,5$ & 275 & 16 & 0,65 & 1 & 23,94 & \multirow{2}{*}{21,76} & Dirawat \\
\hline $2(7)$ & 12,800 & 300 & 150 & 9,83 & 7 & $17.671,5$ & 225 & 13 & 0,65 & 1 & 19,59 & & Dirawat \\
\hline $1(14)$ & 12,895 & 300 & 150 & 9,83 & 14 & $17.671,5$ & 320 & 18 & 0,88 & 1 & 20,58 & \multirow{2}{*}{21,38} & Dirawat \\
\hline $2(14)$ & 12,865 & 300 & 150 & 11,32 & 14 & $17.671,5$ & 345 & 20 & 0,88 & 1 & 22,19 & & Dirawat \\
\hline $1(28)$ & 12,760 & 300 & 150 & 11,32 & 28 & $17.671,5$ & 390 & 22 & 1 & 1 & 22,07 & \multirow{2}{*}{20,94} & Dirawat \\
\hline $2(28)$ & 12,850 & 300 & 150 & 11,32 & 28 & $17.671,5$ & 350 & 20 & 1 & 1 & 19,81 & & Dirawat \\
\hline $1(7)$ & 12,400 & 300 & 150 & 10,58 & 7 & $17.671,5$ & 200 & 11 & 0,65 & 1 & 17,41 & 17,41 & Tidak dirawat \\
\hline $1(14)$ & 12,785 & 300 & 150 & 10,58 & 14 & $17.671,5$ & 230 & 13 & 0,88 & 1 & 14,79 & 14,79 & Tidak dirawat \\
\hline $1(28)$ & 12,630 & 300 & 150 & 10,58 & 28 & $17.671,5$ & 185 & 10 & 1 & 1 & 10,47 & 10,47 & Tidak dirawat \\
\hline
\end{tabular}

\section{KESIMPULAN DAN SARAN}

Berdasarkan hasil pengujian dan pengamatan langsung yang dilakukan dapat disimpulkan sebagai berikut:

1. Untuk uji kuat tekan Semen A lebih unggul dibandingkan dengan Semen B pada semua umur beton.

2. Pemberian perawatan sangat berpengaruh terhadap hasil pengujian, dengan melakukan perawatan (curing) mutu beton yang dihasilkan lebih tinggi dari pada beton yang tidak dilakukan perawatan pada semua jenis semen yang digunakan.

3. Penurunan mutu beton cukup tinggi pada Semen B sebagai semen pendatang baru di industri semen Indonesia, dengan persentase penurunan mutu sekitar $33,42 \%$, hampir dua kali lipat dibanding dengan Semen A dengan persentase penurunan mutu sekitar $16,48 \%$.

Sedangkan saran yang diberikan adalah :

1. Alat uji kuat tekan Compression Testing Machine harus benar-benar akurat, serta pembacaan jarum beban maksimal harus teliti dan cermat.
2. Untuk dapat melakukan penelitian lebih lanjut seperti pemilihan atau pemakaian jenis semen yang lebih beragam lagi, jenis dan asal material yang berbeda, serta dengan mutu dan umur pengujian yang lebih beragam lagi dan metode perawatan yang berbeda.

\section{UCAPAN TERIMA KASIH}

Terima kasih kepada seluruh pihak yang telah membantu pelaksanaan penelitian ini. Selain itu, ucapan terima kasih juga diberikan kepada PT. Riau Mas Bersaudara dan Laboratorium Beton Jurusan Teknik Sipil Universitas Abdurrab yang telah memfasilitasi dalam pengujian mutu beton.

\section{DAFTAR PUSTAKA}

Anam, M. S., \& Trianto, W. (2013). Pengaruh Penggunaan Bone Ash dan Rice Husk Ash Terhadap Sifat Mekanis Pasta Semen. Prosiding Konferensi Nasional Teknik Sipil 7. Universitas Sebelas Maret, (Surakarta, 24-26 Oktober 2013), 71-79. https://fdokumen.com/document/pengaruh -penggunaan-bone-ash-dan-rice-husk-ashlimbah-tulang-hewan-sendiri-sangat.html 
Angjaya, N., Kumaat, E. J., Wallah, S. E., \& Tanudjaja, H. (2013). Perbandingan Kuat Tekan Antara Beton dengan Perawatan pada Elevated Temperature dan Perawatan dengan Cara Perendaman serta Tanpa Perawatan. Jurnal Sipil Statik Universitas Samratulangi, Manado, 1(3), 153-158. https://ejournal.unsrat.ac.id/ index. php/jss/article/view/937

Basri, D. R., Husnah, H., \& Agusrianto. (2019). Analisa Perbandingan Dua Merek Semen dengan Kebersihan Material Terhadap Kuat Tekan Beton K-250. Jurnal Rab Construction Research (RACIC) Universitas Abdurrab. Pekanbaru, 4(1), 20-31. http://jurnal.univrab.ac.id/index. php/racic/article/view/1038.

Hasibuan, M. H. M. (2019). Pengaruh Cara dan Lama Perawatan Terhadap Kuat Tekan Beton. Buletin Utama Teknik. Fakultas Teknik UISU Medan, 14(2), 149-154. https://jurnal.uisu.ac.id/index.php/but/artic $\underline{\text { le/view/1100 }}$

Husna, H. (2016). Analisa Perencanaan Beton Mutu Tinggi (High Strength Concrete) dengan Semen Holcim. Jurnal Rab Construction Research (RACIC)Universitas Abdurrab Pekanbaru, 1(2), 134-144. http://jurnal.univrab.ac.id/index. $\mathrm{php} / \mathrm{racic} / \mathrm{article} / \mathrm{view} / 167$

Nadia \& Fauzi, A. (2011). Pengaruh Kadar Silika Pada Agregat Halus Campuran Beton Terhadap Peningkatan Kuat Tekan. Jurnal Konstruksia, 3(1), 35-43. https://jurnal.umj.ac.id/index.php/konstru ksia/article/view/244

Nugraha, P., \& Antoni,A. (2010). Teknologi Beton dari Material, Pembuatan, ke Beton Kinerja Tinggi. Yogyakarta: Penerbit ANDI

Prayuda, H., \& Pujianto, A. (2018). Analisis Kuat Tekan Beton Mutu Tinggi Dengan Bahan Tambah Superplastisizer dan Limbah Las Karbit. Jurnal Rekayasa Sipil Universitas Muhammadiyah Yogyakarta, 12(1), 32-38. https://rekayasasipil.ub.ac. id/index.php/rs/article/viewFile/485/393
SNI 03-1737-1989. (1990). Tata Cara Pelaksanaan Lapis Aspal Beton (Laston) Untuk Jalan Raya. Badan Standarisasi Nasional.SNI 03-1974. (2011). Cara Perhitungan Kuat Tekan Beton Silinder. Badan Standarisasi Nasional.

SNI 03-1974-1990. (1990). Metode Pengujian Kuat Tekan Beton. Badan Standarisasi Nasional.

SNI 03-2847-2002. (2002). Tata Cara Perhitungan Struktur Beton Untuk Bangunan Gedung. Badan Standarisasi Nasional Bandung.

Harjo, R. (2010). Kuat Tekan dan Porositas Beton Mutu Tinggi dengan Metode Perawatan Steam Curing dan Konvensional. Tugas Akhir. Fakultas Teknik Universitas Muhammadiyah Malang. http://eprints.umm.ac.id/32455/

Romadhoni, N. (2016). Analisis Variasi Metode Perawatan pada High Volume Fly Ash Concrete Mutu Tinggi Terhadap Sifat Mekanisnya. Tugas Akhir. Fakultas Teknik Universitas Muhammadiyah Surakarta. http://eprints.ums.ac.id/47375 /19/Naspub_nurnaim.pdf

Rommel, E. (2011). Pengaruh Pemberian Perawatan Steam Curing Terhadap Kekuatan dan Durabilitas Beton dengan Semen Pozzolan. Jurnal Media Teknik Sipil Universitas Muhammadiyah Malang, 9(2), 142-154.https://ejournal.umm.ac.id/ index.php/jmts/article/view/1200

Pazlan, C., Aulia, T. B., \& Hasibuan, P. (2019). Pengaruh Substitusi Aditif dan Agregat terhadap Kuat Tekan Beton Mutu Tinggi yang Direndam pada Air Asin. Journal of The Civil Engineering Student Universitas Syiah Kuala Banda Aceh, 1(3), 57-63. http://jim.unsyiah.ac.id/CES/article/view/ $\underline{8984}$

Supriani, F., \& Islam, M. 2017). Pengaruh Metode Perlakuan dalam Perawatan Beton Terhadap Kuat Tekan dan Durabilitas Beton. Jurnal Inersia Universitas Bengkulu, 9(2), 47-54. https://ejournal. unib.ac.id/index.php/inersiajurnal/article/v iew/6680. 